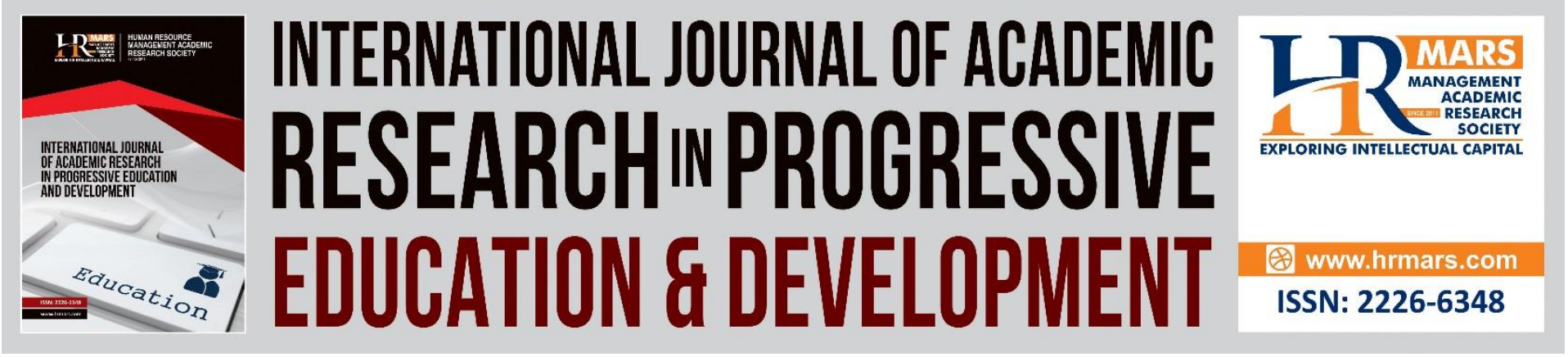

\title{
The Role of Parents in Student Education During Covid-19 Pandemic
}

Miza Rahimy Binti Amirudin, Athirah Batrisyia Binti Ahmat Shahrir, Danial Hakimi Bin Hasan, Fatin Amirah Abd Rahim, Aida Binti Ambotud, Nur Allisa Nabiha Binti Ariff, Nur Nabila Aqilah Binti Hashim, Nurul Ashiqin Binti Mohamad, Izzah Nur Aida Binti Zur Raffar

To Link this Article: http://dx.doi.org/10.6007/IJARPED/v10-i3/11154

DOI:10.6007/IJARPED/v10-i3/11154

Received: 07 July 2021, Revised: 12 August 2021, Accepted: 28 August 2021

Published Online: 29 September 2021

In-Text Citation: (Amirudin et al., 2021)

To Cite this Article: Amirudin, M. R. B., Shahrir, A. B. B. A., Hasan, D. H. Bin, Rahim, F. A. A., Ambotud, A. B., Ariff, N. A. N. B., Hashim, N. N. A. B., Mohamad, N. A. B., \& Raffar, I. N. A. B. Zur. (2021). The Role of Parents in Student Education During Covid-19 Pandemic. International Journal of Academic Research in Progressive Education and Development, 10(3), 902-912.

Copyright: (C) 2021 The Author(s)

Published by Human Resource Management Academic Research Society (www.hrmars.com)

This article is published under the Creative Commons Attribution (CC BY 4.0) license. Anyone may reproduce, distribute, translate and create derivative works of this article (for both commercial and non-commercial purposes), subject to full attribution to the original publication and authors. The full terms of this license may be seen at: http://creativecommons.org/licences/by/4.0/legalcode

Vol. 10(3) 2021, Pg. 902 - 912

http://hrmars.com/index.php/pages/detail/IJARPED

JOURNAL HOMEPAGE

Full Terms \& Conditions of access and use can be found at http://hrmars.com/index.php/pages/detail/publication-ethics 


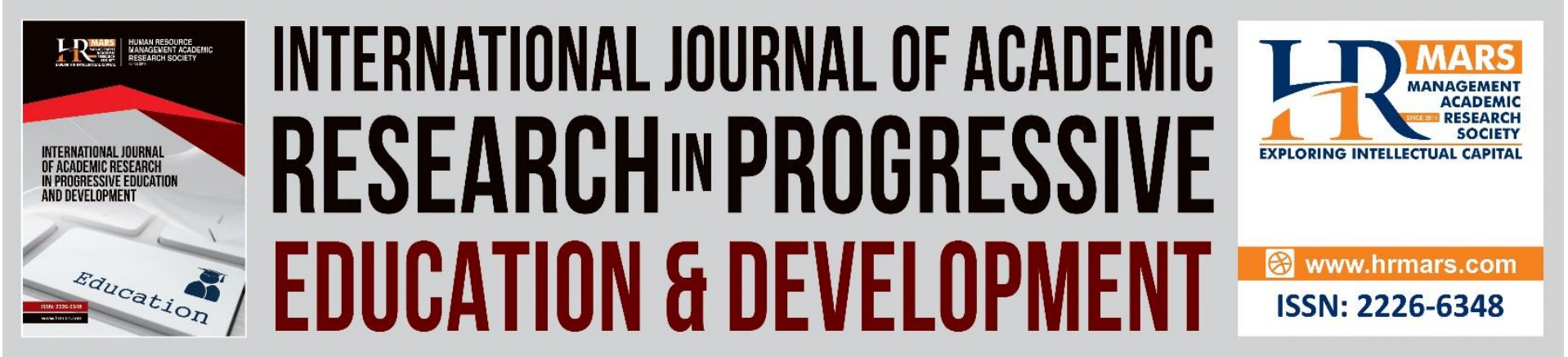

\title{
The Role of Parents in Student Education During Covid-19 Pandemic
}

\author{
Miza Rahimy Binti Amirudin, Athirah Batrisyia Binti \\ Ahmat Shahrir, Danial Hakimi Bin Hasan, Fatin Amirah \\ Abd Rahim, Aida Binti Ambotud, Nur Allisa Nabiha Binti \\ Ariff, Nur Nabila Aqilah Binti Hashim, Nurul Ashiqin Binti \\ Mohamad, Izzah Nur Aida Binti Zur Raffar \\ Universiti Teknologi MARA (UiTM), Melaka Branch
}

\begin{abstract}
The COVID-19 pandemic has changed the pattern of society's life whether in the economic, social, educational and healthy environment to a new normative situation. In terms of education, schools and educational institutions had to be closed as long as the MCO Movement Control Order was gazetted. Many students and teachers are unable to attend school normally due to restrictions on social interaction. As a result, parents have to take over the task of teaching and monitoring their children's online learning at home (PdPr) which requires them to master various subjects, provide internet access and ensure adequate teaching materials. This requires parents to play a very important role in preserving the continuity of student education during the COVID-19 pandemic so that students are not left behind in learning when educational institutions open later. Thus, this study was conducted to examine the pattern of education during the COVID-19 pandemic, identify the role of parents in student learning at home and analyze the readiness of students in facing teaching and learning at home (PdPr). The methodology of this study is qualitative using content analysis design through the method of data collection by a document analysis of books, journal articles, proceedings and akbar related to the title and analyzed descriptively to answer the objectives of the study. The majority of findings of the study show that the role of parents is directly involved in monitoring, providing ongoing encouragement and assisting in student learning activities at home through various applications or digital platforms such as Whatsapp, Google Classroom, Zoom, Webex and Youtube. Further research is proposed to be conducted quantitatively to analyze the level of readiness of students and parents towards digital application based education in new norm and identify the challenges faced by students, parents and educators.
\end{abstract}

Keywords: Student, COVID-19, Education, Parents 


\section{Introduction}

The spread of the Covid-19 pandemic has shocked the whole world which is causing changes in things in everyday life. There were 22 import cases in Malaysia detected in January 2020 by the Ministry of Health (MOH) due to the spread of Covid-19 in Malaysia. However, from day to day the number of positive cases has increased to reach 651 cases of panic among the locals. $18^{\text {th }}$ March 2020, the Malaysian government has had to take decisive steps by introducing the Movement Control Order (MCO) as cases of infection among Malaysians continuously increasing (Salim et al., 2020). The Covid-19 pandemic has made it an attempt by the local community to learn to live within new norms. Life and daily activities have changed a lot. The education sector in institutions of higher learning and lower levels are among those deeply affected by the Covid-19 pandemic.

The Covid-19 pandemic has also made parents play a very important role in students' education in the current situation apart from the role of teachers. This is because the MCO has restricted the movement of out-of-the-house which results in students especially those on the school bench spending a lot of time with their parents at home. Even though confined at home, parents still have to carry out their responsibilities. Parents are responsible for providing education, religion, faith, and morals given the position of family institutions as the first education for their children (Yahaya, 2017). Parents have a great influence especially in the question of students' success in their studies. This is due to the frequent encouragement and enthusiasm of the parents who are confident and hardworking in the learning process. The involvement of parents is very important so that the students can move in line with the demands of education nowadays especially during this pandemic which has many changes in terms of concept and implementation.

If we look deeper, fear of contracting the Covid-19 pandemic will not only become a concern for parents, but also because of the MCO implementation, they are also concerned about losing their jobs which require them to think of alternatives to survive during the MCO (Jafar et al., 2020). In the first quarter of 2020, there was a 42 percent increase in the rate of job losses by Malaysians, among them due to Covid-19 (PERKESO, 2020). Indirectly, parents who were affected by the loss of their jobs would have an impact on the students as their parents' source of income was disrupted by the pandemic. This became more complicated when the Malaysian government decided to close the schools during the MCO to prevent the outbreak from spreading which resulted in the students' learning and teaching ( $\mathrm{PdPr})$ activities being stopped. The closure of schools as a result of this can have an impact on the economic well-being and education of students.

The Covid-19 pandemic caused the PdPr structure which was previously from PdPr methods directly in the institution to be transformed into a fully online PdPr method. The education sector has adopted technology to the maximum due to the norm. Therefore, the method of online learning during PdPr implementation is to use the internet network and the computer media itself. But as of May 2020, 40 percent of students involved in school closures do not have internet access, thus allowing large numbers of dropout students to drop out if the school remains closed and home learning continues (UNICEF, 2020). Prolonged school closures can have an impact on academic stress on students' self-well-being.

To help students' education, children need parents who play an important role in meeting their needs in the aspect of online learning. The new challenge for parents throughout the online PDP is how they can ensure their children do not miss out on learning done online. During the MCO period, online learning sessions could not be effectively 
followed by a large number of students as they did not have access to the appropriate internet and devices. Online learning is also not as specific as face-to-face learning in school. Limited places, no suitable chairs and tables, and a noisy environment are among the problems for underprivileged students when performing homework. Unsatisfactory internet speeds cause communication to become less effective during online presentations.

Based on the above discussion on the issues of the parental role in student education during the Covid-19 pandemic, several objectives can be highlighted, namely, to study the patterns of education during the Covid-19 pandemic, to identify the role of parents in guiding students to ensure a more conducive home learning system, and to identify students' readiness in facing teaching and learning at home ( $\mathrm{PdPr})$.

\section{Educational Patterns Observed During Covid-19 Pandemic}

As we are all aware, education is critical in developing students' quality and ability to adapt to rapid changes in a global society.The Ministry of Education Malaysia (MOE) has implemented the 21st century education system under the Malaysian Education Development Plan (PPPM). It is a student-centered teaching and learning system that incorporates elements of creativity, cooperation, critical thinking, ethical and moral engagement. There are several pedagogies conducted such as co-curricular assessment (KOKU), school-based assessment (PBS), psychometric assessment (PPsi) and others. Furthermore, critical thinking, teamwork, communication, and creativity are other skills that students must cultivate to succeed in 21 st century learning.

The online distance learning method of the 21st century can encourage students to be actively involved, boost morale, and develop high-level thinking skills (HLTS) throughout the learning activities. This is because the pedagogy of 21st century learning has implemented a learning system based on inquiry, projects, problems, STEM approach and PAK21 activities. As a result, students have the opportunity to exchange ideas and perspectives with their peers and teachers, generate creative ideas to produce innovations, cultivate high values and ethics, create simple presentations, solve problems based on real-world scenarios, and actively interact verbally and nonverbally in class. Moreover, the use of technology in the classroom will indeed be essential towards facilitating and assisting students in making progress throughout the 21st century learning process. As a result of the usage of technology, and appealing learning environment may be developed.

However, the global spread of the Covid-19 virus has resulted in dramatic changes in the daily life of each individual. The Covid-19 infection spreads so fast that it can risk people's lives. There is constantly news that reveals a growth in the number of deaths following death cases daily basis throughout the world, therefore the World Health Organization (WHO) has declared Covid-19 as a pandemic. This Pandemic Covid-19 already has negative consequences on health, economics, finances, and the realm of education, which is no exception affected in this exceptional atmosphere, leading in Malaysia and numerous other nations taking measures to implement Movement Control Orders (MCO). Since the MCO was implemented starting March 18, 2020, the focus on hygiene as well as physical and social isolation, has been a continual reminder to stop the Covid-19 virus from spreading. Indirectly, the epidemic has transformed Malaysians' daily lives and taught them to live in a differently

As we all know, these new rules had an impact on the national school system, with the closure of all educational institutions in Malaysia, whether at the elementary or secondary level, to avoid Covid-19 infection. As a result, the educational system must operate entirely 
online. This type of online learning requires commitment from all sides, particularly in terms of information technology expertise and abilities, such as supplying high-quality digital equipment and an internet connection, as well as offering evaluation techniques to evaluate student achievement. As a result, instructors in schools and lecturers in colleges and universities must be educated to conduct online teaching and learning activities to ensure the continuity of the teaching and learning process. Teachers and students must connect using a range of digital apps or platforms suited for online teaching and learning, such as Whatsapp, Google Classroom, Zoom, Webex, and Youtube. Students can review the lesson by rewatching the video recorded by educators or through 'direct' responses received by lecturers, educators and students can do two -way communication. Next is the internal evaluation of student performance online can be assessed through student presentations by video recordings or using other mediums according to the preferences of the educator. Educators frequently use Kahoot apps, Google forms, and other similar tools to expedite the learning process and increase the enjoyment of online teaching and learning process.

The issue arise when online learning was limited to students who had direct exposure to internet access at home that was fast enough to support online learning. Furthermore, Jung et al (2012) indicate that students who go through an online learning process experience psychological issues such as worry and emotional strain. This occurs as a result of challenges faced throughout the online learning process, such as a poor internet connection, device issues, and students having trouble downloading software like AutoCAD, Matlab, and Solidworks, which are required by some subjects. This is because the software can only be accessed for free on campus. This indirectly affects the student's efforts in completing the assignment given. As a result, counseling party support is necessary throughout this movement control to assist students in coping with new learning patterns. Meanwhile, the percentage of students in elementary and secondary schools who have gadgets like tablets, PCs, and laptops is quite low. As a result, students in elementary and secondary schools have significant obstacles when it comes to online teaching and learning. Therefore, parents' involvement in monitoring the growth of children who attend online classes and controlling the content websites viewed by them is important. Here it can be seen that, this Covid-19 pandemic has greatly changed the pattern of the education system throughout the country including in Malaysia and giving a diverse impact on students.

\section{The Role of Parents in Guiding Students at Home}

People frequently say that charity begins at home, which indicates that if we want to do something, start it from below. This is also applicable in this scenario where childrens' behavior and personality will be shaped by their parents. Undoubtedly, parents are the first teachers to their children before they enter the school. According to Termize et al (2021), the early education received by children is part of the responsibilities that parents must fulfill. As a result, the role of parents in educating and guiding children is an effective initiative in shaping the personality of children. Whether we realize it or not, this contagious epidemic originating from Wuhan, China has changed the pattern of education around the world, particularly in Malaysia. It is known that now the MOE has taken the approach to implement home-based teaching and learning (PdPR). This situation has certainly had a significant impact on the students as they are still adjusting to the use of gadgets and online learning.

Parents can be great role models for their children at home, so instead of acting like a crab teaching their children to walk straight, parents need to set a good example to be 
followed. In reality, it is undeniable that the role of parents in monitoring children's activities and behavior during PdPR sessions should be emphasized. This could help to ensure that students behave politely throughout the PdPR session. Normally, students used to look for their teachers to ask any questions that came to mind, but now, the role of teachers has changed since they cannot meet their teachers face-to-face (Hairia'an \& Dzainudin, 2020). Moreover, parent's role towards students also has changed especially during the home-based teaching and learning session. The most significant fact is for parents to educate their children to respect their teachers and others so that they can show good values during online classes. As featured in the Buletin Utama (TV3), we can see various types of students' behavior while participating in online classes. Indeed, there is no denying that home-based teaching and learning encourages Malaysian students to be more creative. Recognizing this fact, parents should play a proactive part in monitoring and observing their children during PdPR sessions.

Parents, on the other hand, should devote some time to teaching and reviewing their children's homework. This is because students are unable to participate in the normal learning process which is face-to-face. According to Jaafar et al (2020), students are required to attend online classes using Google Meet as an online teaching platform where has become a major concern for parents as they are worried that their children may not be able to concentrate during the learning session. Furthermore, unforeseen circumstances such as network outages might also lead students to lose focus during PdPR. Therefore, the responsibility of teachers will be transferred to parents, who will be responsible for reviewing their children's homework. This is to ensure that, even if students only attend virtual classes, their grasp of what they are on par with what they would learn in a physical class. In addition, the homework assigned by the teacher might be used to assess the students' understanding. As a bonus, parents can also strengthen their family relationships by spending time with their loved ones.

Next, in the life of the new norm, parents must get involved actively and horizontally in the learning and development of children from which they do normally. Moreover, because most of the education now occurs in the home environment rather than at school, without the presence of a teacher physically. The role that should be practiced for parents against their children is that parents can supply a conducive and appropriate learning space. This is because, throughout the pandemic period, schools had held classes online such as popular virtual classes are used for students so that space comfortable and conducive should be emphasized to help them learn with more thorough and focused. Furthermore, this can prevent children from being disturbed by the noise around them. Among the tools that need to be provided by parents is that they can be folding tables and appropriate technology tools to use during online classes. Students and parents also need to make sure their children's stationery and learning materials are sufficient to facilitate student and parent affairs. This is because, in times of pandemic, society does not encourage to leave except on important matters.

Since the outbreak of the disease Coronavirus 2019 (Covid-19), the community has taken a variety of conducive ways and tracks to ensure their children will continue to learn even around they are not the same as before Covid-19 spread in our country. Closing at the whole country greatly affects the lives of the people of all occupations and all ages as well as poor, middle class and capable especially in children where some of them are very excited to meet friends-eat however due to the pandemic sacrifice is necessary done. In Malaysia, the expansion of PKP happens, it has a huge impact and makes teachers and students feel anxious. But from a positive perspective, this is like the spirit and responsibility of "giving 
back", i.e to educate the child as much as possible when the parents are usually at home. In addition, parents can help their children get information and PdPR assignments given by teachers. PdPR can be said to be learning performed in any strategic and suitable location. If you can access the Internet and use equipment that allows students to take courses in line, PdPR will be implemented. However, not all students have their tools. They have to borrow their parents 'tools to learn. Therefore, parents should be a key role in telling those in school whether the teacher delivering new news or new assignments outside of school hours. It can help students to always be aware of the most recent assignments given by the lecturer. This process needs to be emphasized to both parents to sharpen abilities and virtues as good examples and dedication to upholding disciplinary rules for performing all assignments assigned by their teachers will be amortized as best as possible so that they can practice order in life consistently.

In addition, parents should also be informed of any news that befell their children like their children were unhealthy and have unavoidable issues. If many students are not present, it will put pressure on the teacher. The pandemic Covid-19 tests the patience and ability of all parties. Such as discussed, communication between the two parties is very important for pleasure their children. They need to be open on behalf of their teacher and listen to the opinions and suggestions of their parents. If teachers can listen to their parents 'suggestions, this can also enable teachers to increase the spirit of learning among all students.

\section{Students' Readiness To Face Teaching \& Learning At Home}

A relaxed, comfortable, and peaceful environment at school is required for every student through from primary school to student higher education to confirm that learning and teaching can be done comfortably and exhilaratingly. This is real as students undergo their lives at school and university throughout their day. Learning in schools and places of study for students is a major factor influence in ensuring the success of teaching and learning of students. Circumstances this positive causes teaching and learning in schools to create an atmosphere good as students can prepare physically and mentally. It has an impact on both the students and the teaching staff to focus on the learning process. Teaching and face-toface learning can make it easier for students to interact between students and teachers so that the required knowledge can be obtained adequately. Friend guidance classmates can also help raise the spirits of students to gain knowledge in school.

However, the Covid-19 pandemic has become a storm in the lives of every student to undergo learning as their lives have changed drastically where they are no longer able to pay full attention to the learning process. The heat of this problem is increasingly felt because students are not able to focus fully and have maximum cooperation. This is related to the factor of the absence of parents at home to monitor the online learning process of their children involved. Eventually, students will lose the spirit and direction to seek knowledge during the teaching and learning process. In such cases, the relevant parties need to take steps to ensure that students are ready to face learning at home and prevent students from being distracted and losing focus in the long run.

The willingness and enthusiasm of students to go through online learning is a matter that must be given full attention as students are the main thing in the learning process and education delivered. Although the teaching staff exerts full energy to educate students, if there is no response and participation from students, then the learning objectives will not be achieved perfectly. To ensure that students participate and understand the content and 
objectives presented by the instructors, students must be responsible and honest with themselves to be ready to receive the knowledge shared from them. The presence of students in the classroom while online is not just sitting in front of their computer or cell phone, but they should also give full cooperation and attention. The excuse that we often hear is that students are not able to focus during teaching and learning which is a big challenge for the teaching staff. Students should ask questions, ask questions and ask for guidance from friends and teachers so that they better understand and accept the knowledge that is poured out. The content of the daily learning can be obtained if the students are prepared spiritually and physically to seek knowledge on that day. An old proverb once said that if you want a thousand strengths, you don't want a thousand excuses, which means that if a person wants to do one thing, he must try his best without complaining.

Home-based teaching and learning (PdPR) is teaching and learning that will be done in the student's home. In other words, it can also be implemented online or offline. Homebased teaching and learning (PdPR) are done when students are unable to attend school due to reasons such as disasters or epidemics for a long period with the approval of the state government. Therefore, school children and university students must adapt themselves to the new learning methods and prepare for teaching and learning at home. According to studies reviewed by lqbal \& Bhatti (2015) found that readiness about online learning can be compared through two aspects, such as from skills preparation aspect and psychological readiness aspect (Ling \& Effendi, 2020). The readiness of students in facing teaching and learning at home in terms of skills can be seen from the adaptation of students when learning to use the line in the school that has already begun. This is because KPM has introduced Sekolah Bestari where the school has 88 schools in Malaysia. Smart School or known as Smart School is one of the school concepts in Malaysia where computer technology allows diversity to be built and created in the education system and the use of the latest technology has been made the main method in teaching and learning techniques. According to Associate Prof Dr. Mahizer Hamzah, the Senior Lecturer of the Department of Educational Studies told that school teachers have used this online learning in support of conventional learning conducted in the classroom at school.

However, in the early stages of its use, it is very limited due to only some teachers using the method. In addition, most teachers have used online learning methods as a repository for students to obtain and use learning materials in the form of PowerPoint Presentations and notes in PDF format. In addition, the readiness of university students' skills to face teaching and learning at home or online can be seen through e-learning where the teaching and learning use computers and the Internet as the main components of learning and teaching. Many universities have used the e-learning method on their university students and one of the universities that use the method is Universiti Teknologi Mara (UiTM) (Endut et al., 2012). In addition, according to Rung et al (2014), it is very important for school children and university students in understanding the skills of users of new tools and students' attitudes towards learning new tools as the main method of learning for the development of appropriate innovation. Therefore, in the sense of education, teachers or instructors must know and take into account the readiness of school children and university students in terms of knowledge to use new tools and skills before starting the use of mobile technology as their main method when learning from home.

In addition, according to the study studied by Ruxwana and Msibi (2018), there are two new dimensions of readiness namely basic readiness or known as device readiness, and 
as well as expenditure readiness. The basic readiness in the survey is to find out whether students already have devices such as mobile phones, laptops, and tablets at home to face teaching and learning online. This basic readiness also focuses on the readiness of students for mobile learning where learning is followed by insufficient time for them and learning materials from various sources through mobile technology where it is using a tablet or smartphone. Thus, the results of a study from Ling and Effendi (2020) found that smartphones are one of the most popular mobile device technologies and are also owned by students and also followed by laptops. Therefore, from the aspect of basic readiness such as mobile devices have been done by students in advance where mobile devices such as phones have now become their daily lives and it is no longer unfamiliar to use the device. From other aspects such as the readiness of spending, it was found that the use of mobile devices to perform learning activities will burden users. This is because teaching and learning use a high rate of the internet where after the family may not be able to provide continuous internet for their children. Moreover, some university students are also not ready to incur excessive additional costs such as additional data costs for mobile device tools for online learning (Ling \& Effendi, 2020).

\section{Conclusions}

The outbreak of the Covid-19 virus has been a major cause of the economic and financial impact on a family. Various ways can be done to ensure the future of children to be more secure as they are the future of the country. Apart from parents, other parties also play a crucial role to assist those in greater need. Hence, the importance responsibility of parents to ensure the comfort of their children during the online learning system. Among the suggestions that need to be proposed are providing internet networks to those who are in rural areas, as well as the students in need who are very limited in having the comfortable facility during online learning. Therefore, Kementerian Pendidikan Malaysia (KPM) needed to issue a clearer guideline such as e-learning to give justice to all students.

It can be said that not all students come from good families as some of them have been living in such remote areas which are Felda and Tanah Merah villages. Thence, providing a stable internet network at their place can help them to focus on the new norm of learning. This issue has been discussed and the breadth of a good internet network is what the students hope for. In addition, the government should pay more attention to assist to students who have problems in terms of learning provision for example aiding with gadgets such as laptops and tablets. Thus, it can help students to be in a state of readiness to follow the Teaching and Learning at Home (PdPR).

Besides that, this coronavirus has been presenting new challenges to all parties, especially to educators but it is not a barrier for students as well as educators to continue learning sessions. Thence, in ensuring that students gain knowledge more smoothly, KPM needs to issue clear e-learning guidelines to provide justice to all students. E-learning is not an option but a necessity for educators and students. KPM can set e-learning time to make it more systematic and orderly. In addition, it can avoid harm to students with minimize their screen time on a laptop. By upgrading e-tv programs for education with increasing the number of subjects and channels is one of the ways to help students who have a financial problem to buy computers and mobile phones. KPM is also advised to provide e-books for free to prevent the spread of the virus. E-books can make it easier for students to access textbooks and exercises at any time. 
DEVELOPMENT

Vol. 10, No. 3, 2021, E-ISSN: 2226-6348 @ 2021 HRMARS

Finally, the outbreak of this virus has created an atmosphere where society is more focused on student learning. Parents were responsible to ensure that the online learning system is more conducive for children and some parties play main roles in helping the students to continue learning and consider this PdPR as one of the new norms for them. The learning of new norms can be continued well as a result of strong cooperation from all parties such as parents, teachers, the community and the government. It can be said that this pandemic will take longer to recover. Apart from praying, we must work to eradicate the Covid-19 virus epidemic and play our respective roles so that the country can move forward and be free from the Coronavirus.

\section{Acknowledgment}

This project is funded under the Teja Grant (GDT2021/1-8), Universiti Teknologi MARA (UiTM), Melaka Branch. The highest appreciation to Universiti Teknologi MARA (UiTM), Melaka Branch for the assistance given to this project.

\section{Corresponding Author}

Izzah Nur Aida Binti Zur Raffar

Academy of Contemporary Islamic Studies (ACIS), Universiti Teknologi MARA, Melaka Branch, Alor Gajah Campus, 78000 Alor Gajah Melaka, Malaysia.

Email: izzahnur@uitm.edu.my

\section{References}

Endut, A., Isa, P., Aziz, S., Jono, M., \& Aziz, A. (2012). e-Learning for Universiti Teknologi MARA Malaysia (UiTM): Campus Wide Implementation and Accomplishments. Procedia Social and Behavioral Sciences, 67, 26-35.

Hairia'an, N. H., \& Dzainudin, M. (2020). Pengajaran dan pemudahcaraan dalam talian semasa perintah kawalan pergerakan. Jurnal Pendidikan Awal Kanak-Kanak Kebangsaan, 9, 1828.

Iqbal, S., \& Bhatti, Z. A. (2015). An investigation of university student readiness toward Mlearning using technology acceptance model. International Review of Research in Open and Distance Learning, 16(4), 83-103.

Jaafar, N. F., Zain, A., \& Eshak, Z. (2020). Peranan Ibu Bapa Dalam Membantu Perkembangan Sosial Kanak-Kanak Melalui Aktiviti Bermain Semasa Perintah Kawalan Pergerakan. Jurnal Pendidikan Awal Sosial Kanak-Kanak Kebangsaan, 9, 52-60.

Jafar, M. F., Amran, Z. A., Faiz, M., \& Yaakob, M. (2020). Kesediaan Pembelajaran Dalam Talian Semasa Pandemik Covid-19. Conference: Seminar Darulaman 2020 Peringkat Kebangsaan.

Jung, I., Kudo, M., \& Choi, S. K., (2012). Stress in Japanese learners engaged in online collaborative learning in English. British Journal of Educational Technology, 43(6), 10161029.

Ling, T. J., \& Effendi, M. E. (2020). Kesediaan Guru dan Pelajar Terhadap Penggunaan Pembalajaran Mobil dalam Pembelajaran dan Pemudahcaraan (PdPc): Sorotan Literatur Bersistematik. Malaysian Journal of Social Sciences and Humanities (MSJSSH), 5(10), 8394.

PERKESO. (2020). Employment Outlook, the 1st Quarter of 2020. The Impact of COVID-19 on Loss of Employment (LOE). Retrieved from https://eiscentre.perkeso.gov.my/wp- 
content/uploads/2020/06/Employment-Outlook-Volume-4-2020-Loss-ofEmployment.pdf

Rung, A., Warnke, F., \& Mattheos, N. (2014). Investigating the use of smartphones for learning purposes by Australian dental students. JMIR mHealth and uHealth, 2(2), e20.

Ruxwana, N., \& Msibi, M. (2018). A South African university's readiness assessment for bringing your own device for teaching and learning. South African Journal of Information Management, 20 (1), 9-16.

Salim, N., Chan, W. H., Mansor, S., Bazin, N. E., Amaran, S., Faudzi, M. A. A., Zainal, A., Huspi, S. H., Hooi, J. E. K., \& Shithil, S. M. (2020). COVID-19 epidemic in Malaysia: Impact of lockdown on infection dynamics. Retrieved from https://doi.org/10.1101/2020.04.08.20057463

Termize, M., Mohd, R., \& Zamri, A. (2021). Tahap Sokongan Ibu Bapa Dalam Membantu Pembelajaran Murid B40 Di Sekolah Luar Bandar. Jurnal Dunia Pendidikan, 3(1), 707717.

Unicef. (2020). Two thirds of the world's school-age children have no internet access at home, new UNICEF-ITU report. Retrieved from https://www.unicef.org/press-releases/twothirds-worlds-school-age-children-have-no-internet-access-home-new-unicef-itu.

Yahaya, A. (2017). Keluarga dalam Pembentukan Moral. Retrieved from http://eprints.utm.my/id/eprint/6035/1/aziziyahmoral.pdf 